\title{
POLA SEBARAN PLANKTON PADA BERBAGAI SUMBER PENCEMARAN YANG BERBEDA DI SUNGAI MUSI KECAMATAN GANDUS DAN KERTAPATI
}

\author{
Eka Rizki Meiwinda \\ 1) Jurusan Teknik Lingkungan Fakultas Teknik Universitas Baturaja \\ Email : mewizq@gmail.com
}

\begin{abstract}
Industrial activity at Musi River can be impact to plankton community. These experiment has been taken places in 5 station under different industrial wastewater pollution. The study revealed occurance of 13 distribution of plankton based on the station. Station 1 is less different of similarity and closeness from the other station, and station 2,4,5 have less similarity and closeness with station 3 and station 2,3,4,5 have similarity and closeness with station 1 .

ABSTRAK

Aktivitas industry yang berada di Sungai Musi berdampak pada komunitas plankton. Penelitian ini dilakukan dengan mengambil 5 stasiun dengan perbedaan jenis polutan. Hasil yang didapatkan dalam penelitian ini, terdapat 13 sebaran plankton berdasarkan masing-masing stasiun. Stasiun 1 berbeda sedikit sekali persamaan dan kedekatannya dengan stasiun lainnya. Stasiun 2,4,5, dan 3 masing-masing berada pada kuadran 4 dan 2 yang artinya pada stasiun 2,4,5 banyak memiliki kesamaan, namun sedikit sekali memiliki kesamaan dan kedekatan dengan stasiun 3. Stasiun 2,3,4, dan 5 banyak memiliki kedekatan dan kesamaan spesies dengan stasiun1.
\end{abstract}

Key word : Pollution, Musi River, Industry

\section{Pendahuluan}

Perairan Sungai Musi bagian hulu hingga tengah tergolong terpolusi sedang yang terjadi pada beberapa bulan, umumnya antara April dan Juni, sedangkan wilayah Sungai Musi yang tergolong terpolusi berat oleh bahan organik dimulai dari perairan disekitar Gandus hingga ke Muara Sungai Komering. Perubahan fisik lingkungan, jenis, sumber dan sebaran bahan pencemar akan menurunkan kualitas perairan di Sungai Musi. Banyak bahan beracun (bahan antropogenik) yang masuk kedalam suatu ekosistem perairan. Jenis bahan antropogenik tersebut diantaranya bahan organik, lemak, padatan tersuspensi (TSS), logam berat, organoklorin hidrokarbon, pestisida, dan unsur hara (BRPPU, 2010). Bahan antropogenik ini bersumber dari limbah industri pertanian maupun industri non pertanian yang beroperasi di sekitar Sungai Musi Kecamatan Gandus dan Kecamatan Kertapati teradapat industri pengolahan karet yang berbahan baku lateks dan karet kering, stockpile batubara, industri pembuatan semen, dan pabrik kecap. Penurunan kualitas perairan yang diakibatkan banyaknya pencemaran berdampak langsung terhadap aktifitas perairan yang dilakukan di Sungai Musi. Air merupakan tempat hidup bagi berbagai jenis kehidupan diperairan. 


\section{Metode}

Penelitian ini dilakukan di Sungai Musi wilayah Kecamatan Gandus dan Kecamatan Kertapati. Metode penelitian yang dilakukan adalah dengan metode survei untuk mendapatkan data primer dan sekunder. Penelitian ini menggunakan 5 stasiun pengukuran yang mewakili lokasi yang dibedakan berdasarkan daerah yang potensial terkontaminasi yaitu lokasi yang mengalami perubahan kualitas air oleh aktivitas industri (Hadi, 2007) dan aktivitas industri yang terus menerus. Sampling dilakukan pagi hari antara jam 8.00 - 10.00 waktu setempat untuk pengambilan plankton dikarenakan zooplankton yang kebanyankan tidak menyukai sinar matahari.

\section{Hasil}

Tabel 1. Struktur Komunitas Plankton di setiap stasiun pengamatan

\begin{tabular}{llllll}
\hline $\begin{array}{l}\text { Species (ind/Luas lapang } \\
\text { pandang) }\end{array}$ & stasiun 1 & stasiun 2 & stasiun 3 & stasiun 4 & stasiun 5 \\
\hline Holopedium irregular & 0 & 0 & 2 & 0 & 0 \\
Aphanocapsa gravillei & 0 & 0 & 1 & 0 & 0 \\
Gloeotrichia echinulata & 0 & 0 & 0 & 0 & 0,5 \\
Aphanisomenon fiosaquae & 0,5 & 0,5 & 0,5 & 0 & 0 \\
\hline Cerataulina bergonii & 1 & 0 & 1 & 0 & 1 \\
Rhizosolema spp. & 10 & 19,5 & 11 & 11,5 & 12 \\
Hermiaulus hauckii & 0 & 0 & 1,5 & 0 & 0 \\
Striatella interrupta & 0 & 0 & 0,5 & 0 & 0,5 \\
Pleurosigma sp & 0 & 0 & 0,5 & 0 & 0 \\
\hline Pleurotaenium nodosum & 0 & 0 & 0 & 0 & 0,5 \\
Spirogyra pseudocylindrica & 0 & 0,5 & 0,5 & 0 & 0 \\
Sphaerocystis schroeleri & 5 & 0 & 0 & 0 & 0 \\
\hline Dictyocephalus & 0 & 0 & 0 & 0 & 0,5 \\
mediterraneus & 0 & 0 & 1 & 0 & 0 \\
Eucyrtidium butschlii & 1 & 0 & 1,5 & 1 & 1 \\
Lithocampe diploconus & 0 & 0 & 1 & 1,5 & 0,5 \\
\hline Rhabdonella lohmanni & 0 & 0 & 0,5 & 0,5 & 1 \\
Eutintinnus sp & 1,5 & 0 & 0,5 & 0 & 0,5 \\
Helicostomella sp & 0 & 0,5 & 0 & 0 & 0 \\
Parundella longe & 0 & 0 & 0,5 & 0 & 0 \\
\hline Favella franciscana & 0 & 0,5 & 0 & 0,5 \\
\hline Pseudocalanus minutes & 0 & 0 & 0,5 & 0 & 0 \\
\hline Oikopleura sp & & 0 & & & \\
\hline & & 0 & 0 & 0 & 0 \\
\hline
\end{tabular}

\section{A. Analisa Koresponden (Correspondence Analysis)}

Correspondence analysis digunakan untuk menemukan hubungan kedekatan antar spesies dalam masing-masing stasiun setiap minggu. Untuk menginterpretasikan data correspondence ditampilkan dalam grafik. 


\section{Correspondence Analsysis saat Surut Pertama}

Gambar penyebaran dan kesamaan spesies plankton yang ditemukan pada setiap stasiun pengamatan yang dilakukan pada saat surut pertama dapat dilihat pada Gambar 5. sebagai berikut.

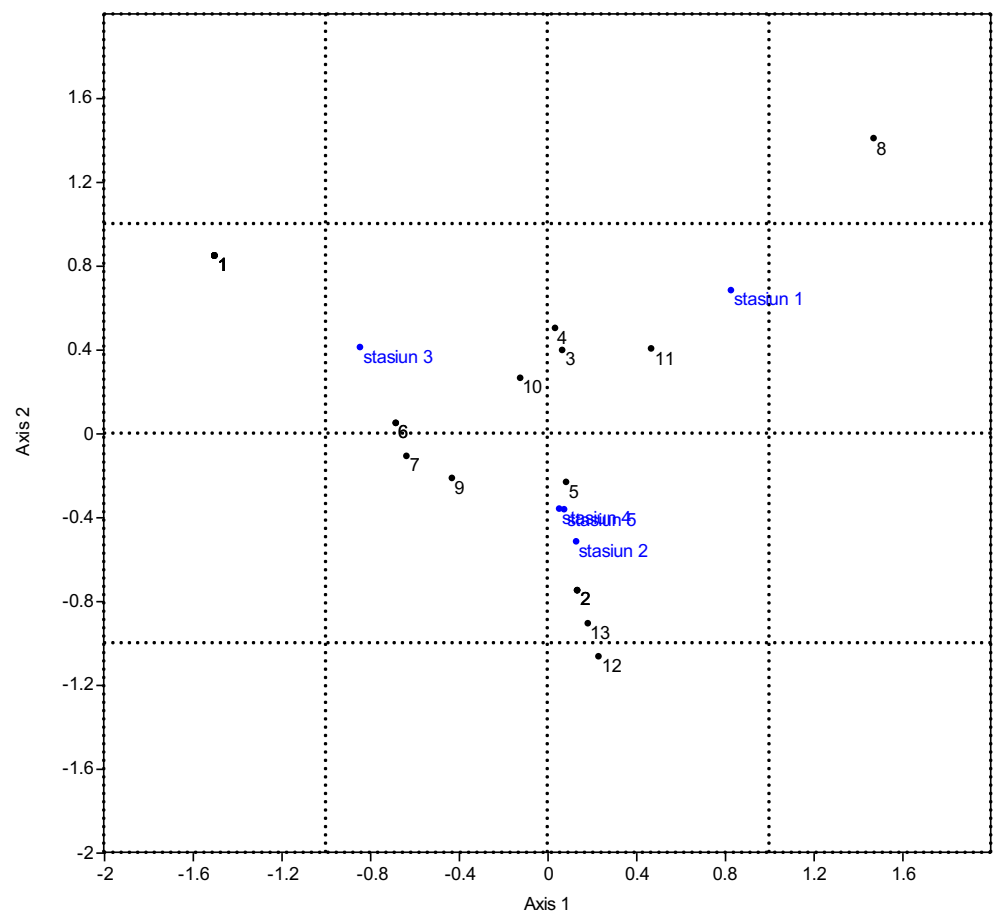

Gambar 5. Penyebaran dan Kesamaan Spesies Plankton dan Masing-Masing Stasiun pada Saat Surut Pertama

Keterangan :

1. Holopedium irregular, Aphanocapsa gravillei, Hemiaulus hauckii, Pleurosigma sp., Favella franciscana, Muggiea atlantica, Oikopleura sp.,

2. Gloeotrichia fiosaquae, Pleurotaenium nodosum, Dictyocephalus mediterraneus,

3. Aphanisomenon fiosaquae, Eucrytidium butschlii

4. Cerataulina bergonii,

5. Rhizosolemma sp.,

6. Striatella interrupta,

7. Spirogyra pseudocylindrica,

8. Sphaerocystis schroeleri,

9. Lithocampe diploconus,

10. Rhabdonella lohmanni,

11. Eutintinnus sp.,

12. Parundella longe,

13. Pseudocalanus minutes,

Berdasarkan Gambar 5., stasiun 1 berada pada kuadran 1 yang artinya stasiun 1 berbeda sedikit sekali persamaan dan kedekatannya dengan stasiun lainnya. Stasiun 2,4,5, dan 3 masingmasing berada pada kuadran 4 dan 2 yang artinya pada stasiun 2,4,5 banyak memiliki kesamaan, namun sedikit sekali memiliki kesamaan dan kedekatan dengan stasiun 3 . Stasiun 2,3,4, dan 5 banyak memiliki kedekatan dan kesamaan spesies dengan stasiun1. 
Spesies Sphaerocystis schroeleri hanya ditemukan di stasiun 1, spesies Holopedium irregular, Aphanocapsa gravillei, Hemiaulus hauckii, Pleurosigma sp., Favella franciscana, Muggiea atlantica, Oikopleura sp., hanya ditemukan distasiun 3. Gloeotrichia echinulata, Dictyocephalus mediterraneus dan Pleurotaenium nodosum ditemukan di stasiun pengamatan 5. Spesies Parundella longe hanya ditemukan di stasiun 2. Pseudocalanus minutes ditemukan di stasiun 2 dan 5. Rhizosolemma spp. ditemukan disemua stasiun pengamatan, sedangkan Cerataulina bergonii ditemukan di stasiun 1 dan stasiun 3. Aphanisomenon fiosaquae ditemukan distasiun 1,2, dan 3. Striatella interrupta ditemukan di stasiun 3 dan 5. Spirogyra pseudocylindrica ditemukan distasiun 2 dan 3. Lithocampe diploconus dapat ditemukan di stasiun 1,3,4, dan 5. Rhabdonella lohmanii dapat ditemukan di stasiun 3,4, dan 5. Stasiun 2, 4, dan 5 hampir memiliki jenis plankton yang sama sehingga titik pada gambar penyebaran diatas berdekatan. Sedangkan stasiun 1 dan stasiun 3 sedikit sekali memiliki kesamaan dengan stasiun lainnya.

\section{Kesimpulan}

Stasiun 1 berbeda sedikit sekali persamaan dan kedekatannya dengan stasiun lainnya. Stasiun 2,4,5, dan 3 masing-masing berada pada kuadran 4 dan 2 yang artinya pada stasiun 2,4,5 banyak memiliki kesamaan, namun sedikit sekali memiliki kesamaan dan kedekatan dengan stasiun 3. Stasiun 2,3,4, dan 5 banyak memiliki kedekatan dan kesamaan spesies dengan stasiun1.

\section{Daftar Pustaka}

APHA. 1989. Standard Method for Examination of Water and Waste Water : $14^{\text {th }}$ Edition. APHAAWWA-WPCF. Washington DC.

Balai Riset Perairan Umum, 2010. Perikanan Perairan Sungai Musi Sumatera Selatan. Bee Publishing. Palembang.

Basmi, H.J. 2000. Planktonologi : Plankton sebagai Indikator Kualitas Perairan. Fakultas Perikanan dan Ilmu Kelautan Bogor. Bogor.

Effendi, H. 2003. Telaah Kualitas Air : Bagi Pengelolaan Sumber Daya dan Lingkungan Perairan. Penerbit Kanisius. Yogyakarta.

Fahrezi Hsb, H., Mulya, M. B., dan Leidonald, R. 2014. Keanekaragaman Plankton Di Perairan Sungai Asahan Sumatera Utara. Jurnal Aquacoastmarine. Volume : 3. No : 2. Tahun 2014.

Ginting, P. 2007. Sistem Pengelolaan Lingkungan dan Limbah Industri. Yrama Widya: Bandung.

Mayagitha, K. A., Haeruddin, Rudiyanti, S. 2014. Status Kualitas Perairan Sungai Bremi Kabupaten Pekalongan Ditinjau dari Konsentrasi TSS, BOD5, COD dan Struktur Komunitas Fitoplankton. Diponegoro Journal Of Maquares. Volume : 3, Nomor : 1, Tahun : 2014, Halaman 177-185.

Nybakken, J.W. 1992. Biologi Laut : Suatu Pendekatan Ekologis. Terjemahan oleh Eidman et al. Gramedia Pustaka Utama. Jakarta.

Odum, E.P. 1998. Dasar-Dasar Ekologi. Terjemahan oleh : Samingan, T. dan Srigandono, B. Gajah Mada University Press. Yogyakarta. 
Pemprov TK 1. SUMSEL. Pemerintah Provinsi Daerah Tingkat I Sumatera Selatan. 1997. Laporan Tahunan Program Kali Bersih Sungai Musi Periode 1996-1997. Palembang. Pemprov TK.1 Sumsel.

Soegianto A, 2004. Metode Pendugaan Pencemaran Perairan dengan Indikator Biologis. Surabaya: Airlangga University Press.

Wijaya, T.S., dan Hariyati, R. 2011. Struktur Komunitas Fitoplankton sebagai Bio Indikator Kualitas Perairan Danau Rawapening Kabupaten Semarang Jawa Tengah. Jurnal Anatomi Fisiologi. Vol 19, No 1 (2011): Volume XIX, Nomor 1, Maret 2011.

Zulkifli, H., Husnah., Ridho, M.R. dan Juanda, S. 2009. Status Kualitas Sungai Musi Bagian Hilir Ditinjau Dari Komunitas Fitoplankton. Jurnal berk. Penel. Hayati. Volume 15 halaman 5-9 tahun 2009. 